\title{
APPLICATION OF GRAPH THEORY TO THE MORPHOLOGICAL ANALYSIS OF SETTLEMENTS
}

\author{
ROBERT SZMYTKIE \\ Institute of Geography and Regional Development, University of Wrocław, Poland \\ Manuscript received: September 1, 2017 \\ Revised version: November 23, 2017
}

\begin{abstract}
SzmYTKIE R., 2017. Application of graph theory to the morphological analysis of settlements. Quaestiones Geographicae 36(4), Bogucki Wydawnictwo Naukowe, Poznań, pp. 65-80, 4 tables, 16 figs.

AвSTRACT: In the following paper, the analyses of morphology of settlements were conducted using graph methods. The intention of the author was to create a quantifiable and simple measure, which, in a quantitative way, would express the degree of development of a graph (the spatial pattern of settlement). When analysing examples of graphs assigned to a set of small towns and large villages, it was noticed that the graph development index should depend on: a relative number of edges in relation to the number of nodes ( $\beta$ index), the number of cycles (urban blocks), which evidences the complexity of the spatial pattern of settlement, and the average rank of nodes of a graph, which expresses the degree of complexity of a street network.
\end{abstract}

KEY WORDS: graph methods, morphological analysis, morphology of settlements, Silesia (SW Poland)

Corresponding author: Robert Szmytkie, Institute of Geography and Regional Development, University of Wroctaw, pl. Uniwersytecki 1, 50-137 Wroctaw, Poland, e-mail: robert.szmytkie@uwr.edu.pl

\section{Introduction}

The beginnings of the discussion concerning the issues of morphology and physiognomy of settlements date back to the end of the 19th century. The precursor of modern geography of settlements, Otto Schlüter (1899), emphasised the importance of research on cultural landscape morphology in human geography. Moreover, Schlüter postulated that in settlement research it is vital to analyse: a geographic and topographic location of settlements, their spatial organisation (plan) and physiognomy of settlements, which serve as a base for further analyses of origins and functions of settlements. Studies which raise the subject of morphology and physiognomy of settlements currently belong to one of the most important ones within settlement geography (Whitehand 1987, 1992).
However, the issue of morphology and physiognomy is examined separately with reference to various types of settlements. In the case of rural settlements the research concentrates on the issue of morphology and its relations to the origin of settlements, wherein the morphology is considered from the perspective of spatial distribution of settlements, as well as land layouts within villages (Lienau 1973; Szulc 1995; Tkocz 1998). In the case of urban settlements the analysed features are morphology and physiognomy, considered as elements which make up for the spatial structure of a town. Contemporary research concerning the morphology of cities around the world is based on the methods of analyses of town plans, also known as conzenian methods (Conzen 1960; 1962; 1968; Whitehand 2001; Koter, Kulesza 2010), or concentrate on application of statistical methods, as well as sophisticated techniques 
and modelling using a GIS method (e.g. Harris 1985; Levine, Landis 1989; Páez, Scott 2004), an example of which can be found in "space syntax" (Hillier, Hanson 1984; Hillier 1996; Ratti 2004).

In the following paper, the analyses of morphology of settlements were conducted using graph methods, which refer to the research conducted at the University of Wrocław in the 1960s and 1970s (Zagożdżon 1970; 1977). The intention of the author was: (1) to create a quantifiable and simple measure with considerable analytical possibilities, which, in a quantitative way, would express the degree of graph development (its spatial pattern); (2) to verify the proposed index on the example of settlements encompassing small towns and big villages located in the south-west region of Poland. An analytical part of the study aims at the verification of the following research hypotheses:

- The morphology of settlements mainly depends on the category of a settlement (urban rural), settlement history, its size (population) and location.

- Urbanisation processes taking place in rural areas lead to a gradual reshaping of rural to urban, which is also reflected in the morphology of settlements. This applies in particular to suburban areas, non-agricultural villages and large villages located far from main urban centres.

- Within the given types of settlements the greater morphological diversity is demonstrated by: (1) units formed in a spontaneous way rather than by units formed in a planned manner; (2) settlements undergoing dynamic changes in recent years rather than by settlements developing in a long-term and evolutionary way; (3) larger rather than by smaller settlements.

\section{Graph theory in settlement research}

Graph theory, considered as a branch of mathematics, finds a broad use in geographical sciences, where a research structure plays an important role. Mathematical models formulated on the basis of graph theory make a description of structure elements possible, as well as the identification of more complicated relations between them (Tinkler 1977; Öre 1990; Runge 2006). In social economic geography graph methods, as yet, were applied to (Haggett, Chorley 1969; Harary 1969; Taylor 1974; Tinkler 1977; Hage 1979; Gross, Yellen 1999; Arlinghaus et al. 2002; Beineke, Wilson 2004; Runge 2006; Jażdżewska 2008; Newman 2010):

- studies of the structure of transport systems (Kansky 1963; Garrison 1968; James et al. 1970; Taylor 1975; Ratajczak 1980; Ducruet, Lugo 2013) or street networks (Porta et al. 2006; Xie, Levinson 2007; 2009; 2011);

- delimitation of nodal regions (Nystuen, Dacey 1968);

- defining relative significance of subspace in the hierarchical system of geographical space and creating hierarchies (Doi 1969);

- modeling of processes of innovation diffusion (Eoboda 1973);

- researching the structure balance in social geography (Harary 1970);

- historical geography (Jażdżewska 2008);

- settlement geography in researching settlement networks and systems (Haggett 1965; Zagożdżon 1970; 1977; Golachowski et al. 1974; Miszewska 1976; Moriconi-Ebrard 1993; Jażdżewska 2008), hierarchical ordering of settlements (Maik, 1977; Jażdżewska, 2008), and the morphology of settlements (Zagożdżon 1970; 1977; Krüger 1979; Thomson, Richardson 1995; Drobek 1999; Marshall 2004; Szmytkie 2009; Dymitrow 2012).

Zagożdżon (1970; 1977) claims that graph theory in settlement studies may find an application in the research on the morphological structure of settlements (both single settlements and settlement networks), as well as in functional analyses; in both approaches it is possible to conduct statistical and dynamic analyses. Applying the graph method in the analysis of the distribution of settlements requires certain theoretical assumptions which result from general graph theory. In reference to the definition, which treats a graph as a geometrical figure consisting of nodes and the edges joining them (Öre 1962). Zagożdżon (1970; 1977) made the following assumptions:

- the shape of a graph depicts the structure (morphology) of a settlement, understood as buildings aligned in a specific form along particular roads and streets; 
- nodes are single housing units occurring as "points", as well as ends of parts of streets (roads) filled with buildings;

- edges are connections between nodes (vertices) of a graph; in such an approach an edge is a stretch of buildings aligned along a street which connects the end points (nodes) of a graph.

Depending on the degree of development of spatial distribution, a settlement can be a system of topographically coupled edges and form a complicated system. It can also consist of separate edges, and even separate nodes. When omitting the simplest forms, e.g. dispersed settlements expressed with null graphs, simple layout settlements consist of at least two nodes which are the two ends of a settlement.

The degree of graph cohesion depends on the number of edges (connections between the nodes). With an increase in the morphological complexity of a settlement, the graph structure becomes more complicated and the rank of particular nodes grows. The following cases can be assumed as end points:

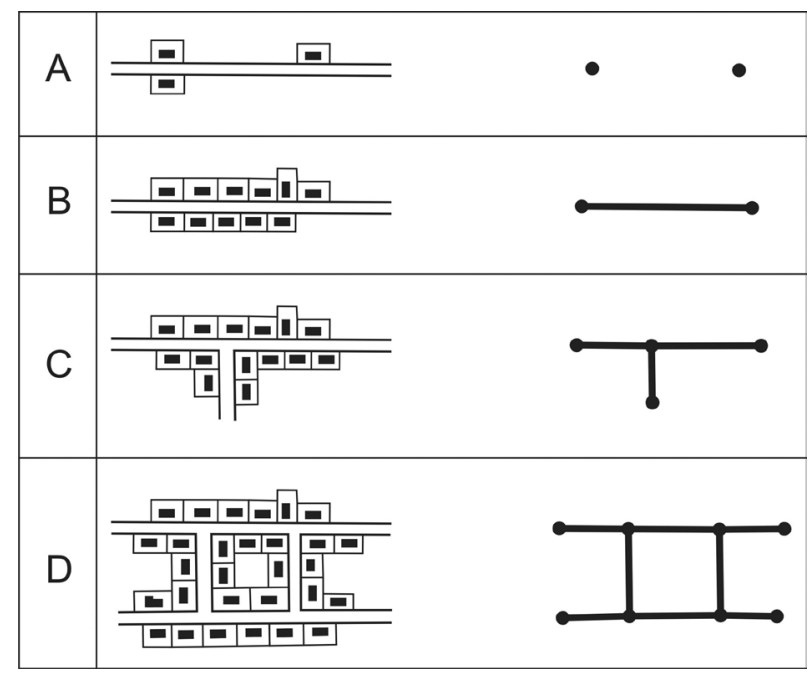

Fig. 1. Graphs identifying morphological layouts of settlements.

A - a dispersed settlement, single buildings or the small concentration of buildings (local in character) located in considerable distance between buildings (a null graph). B - a typical rural settlement with a simple morphological layout (the simplest connected graph).

$\mathrm{C}$ - settlements with a complex structure consisting of two topographically coupled morphological units (a tree-shaped connected graph).

$\mathrm{D}$ - the most complex morphological structure (a cycle graph).

Source: Zagożdżon 1970.
- a null graph $\left(\mathrm{K}_{0}\right)$, which consists only of nodes, and does not include edges;

- a complete graph $\left(\mathrm{K}_{\mathrm{n}}\right)$, consisting of nodes and all possible edges between them.

Zagożdżon (1970; 1977) also distinguishes various forms which can be assumed by graphs (Fig. 1):

- a null graph - a dispersed settlement;

- a connected graph - the simplest connected graph consists of a pair of nodes and one connection between them;

- tree-shaped connected graphs - graphs consisting of $\mathrm{N}$ vertices, maintaining the condition that the number of edges equals $\mathrm{E}=\mathrm{N}-1$;

- cycle graphs - graphs with closed connections, where the number of edges is equal or greater than the number of vertices $(E \geq N)$;

- tree-shaped graphs - graphs consisting of nodes and shortest connections between them. Moreover Zagożdżon (1970) elaborates on the stages of shaping graph structures (Fig. 2) which fall into the following order:

1. Creation of new settlement concentrations as separate units, which in graph theory are identified as separate (incoherent with the existing ones) null graphs.

2. Creation of new morphological units neighbouring directly already existing settlements, which leads to their development and consequently to a complication of their layout. In such a case, the graph enriches its structure not only through forming new nodes, but also

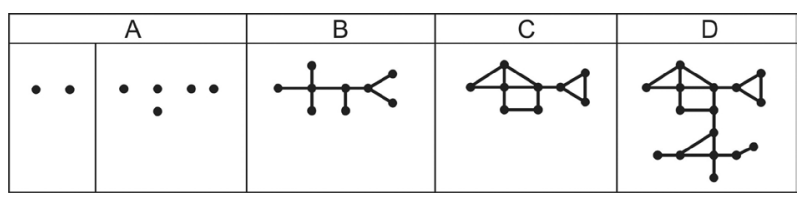

Fig. 2. Shaping stages of a graph structure.

A - single null graphs, formation of new nodes, which do not create a complete graph yet; in this case a graph is a set of unstructured nodes (not coupled topographically).

B - development of a tree-shaped graph; next to existing parts of a graph new nodes and edges are formed; they expand the structure of the existing connected graph. $\mathrm{C}$ - further development of the graph structure; the formation of closed connections (cycles) within the graph structure.

D - complex graphs, and even groups of graphs; higher ranks of structures are created through external inter-settlement connections (the structure resembles a stream capture).

Source: Zagożdżon 1970. 
by increasing the number of new edges. As a consequence, a type of a connected graph - a tree-shaped graph - is created.

3. Considering spatial consequences, further growth of development can take a more developed form which does not result only in the creation of more tree-shaped branches, but also in the creation of closed connections (cycles). The creation of cycles is the beginning of a phase leading to the formation of a complete graph.

4. Creation of higher-rank systems with stream captures (inter-settlement connections). It results in the formation of more complex groups of graphs with characteristic joints indicating the connections of subgraphs.

What is more, in the course of complex analysis of settlement network, Zagożdżon (1970) confirmed a regularity in interdependence between a function and its respective population as well as morphology of the settlement, which, in the graph theory language, is expressed as follows:

- simple graphs, which display simple morphology, make it possible, without a doubt, to draw a conclusion about the monofunctional structure of such a settlement; inhabitants of such settlements should possess traits characteristic of homogeneous structures;

- complex graphs with closed circuits (cycles) usually indicate the presence of polyfunctional systems; inhabitants of such settlements possess traits of a heterogeneous structure (diverse in the case of professions, social status and culture);

- graphs with a network structure exhibit a more advanced urbanisation process (visible also in a technical and spatial sphere), which leads to the spatial and functional integration of particular settlement elements into bigger structures. The elements of network structures are usually subgraphs with a big number of edges and nodes, as well as high measures of graph development.

\section{Construction of the graph development index}

One of the elements which differentiates settlements is their planning. The majority of towns are heterogenic in character, which is a result of their long-lasting development. Because of that, their spatial pattern changes together with socio-economic changes. Hence the layouts of towns are complex in character, where, next to regular districts, there are still elements planned chaotically and in a free-standing manner (Maik 1992). According to Koter (1994), small towns have a complex morphological layout, which is a collection of diverse units when it comes to their planning and the character of development (it is a collection of homogeneous urban settlements). On the other hand, rural settlements can be characterised by simple planning; morphologically complex forms are very rare in such types of settlements (Lienau 1973; Szulc 1995; Tkocz 1998).

The settlement network is usually treated as a physical system of development along roads (known as settlements) and roads which connect them (Miszewska 1976). According to Zagożdżon (1970), particular settlements (as bases for roads) can be associated with a respectively developed graph, thanks to which the spatial structure of settlements can be expressed using formalised language. In order to study the settlement network using graphs, Zagożdżon (1970; 1977) used indices for the analysis of the transportation network introduced by Kansky (1963). Among various indices used for graph profiles (Tab. 1), Zagożdżon (1970) used the following two to determine the structure of settlements: the graph development degree $\left(G_{b}\right)$ and beta index $\beta$ used by Kansky (1963) (however, he claimed that both

Table 1. Some measures of graph structures.

\begin{tabular}{|l|c|}
\hline \multicolumn{2}{|c|}{ Non-ratio measures } \\
\hline Cyclomatic number & $\mu=e-v+p$ \\
\hline Rlpha & $a=\frac{\mu}{\frac{v(v-1)}{2}-(v-1)}$ \\
\hline Beta & $\beta=\frac{e}{v}$ \\
\hline Gamma & $\gamma=\frac{e}{\frac{v(v-1)}{2}}$ \\
\hline & Measures of individual elements \\
\hline Degree of connectivity & $e_{\max }=\frac{v(v-1)}{2}$ \\
\hline Graph development degree & $G_{b}=\frac{1}{2}\left(1-\frac{e}{e_{\max }}\right)$ \\
\hline
\end{tabular}

$e$ - number of edges, $v$ - number of nodes, $p$ - number of isolated subgraphs.

Source: own work based on Kansky (1963) and

Zagożdżon (1977). 
indices aimed at a preliminary and not detailed analysis of settlements as graph systems).

The graph development index is a quantity relative to the class of the graph (as measured by the number of nodes) and it expresses the number of connections missing to form a complete graph, per one node. In his works Zagożdżon $(1970 ; 1977)$ also postulated a modification of the aforementioned index - absolute graph development index $\left(K_{a}\right)$, which expresses an average fraction of lack of connections. $\beta$ index (Kansky 1963) expresses the relation between the elements of the structure and it can assume various values depending on the graph form:

- in null graphs, despite the number of nodes -0 ,

- in partly connected graphs (where separate nodes also occur as null subgraphs) - between 0 and 1 ,

- in connected graphs (where the number of edges equals to $E=V-1$ ) - between 0 and 1 ,

- in connected graphs with 1 cycle (where $E=$ V) -1 ,

- in graphs with more than 1 cycle $(E>V)$ - always more than 1 .

What is more, Zagożdżon (1977: 161-162) believed that "none of the patterns depicts all of the features of a graph structure", hence: "because of the lack of synthetic measures, a whole series of 'analytical' measures can be used; each of them reacting to slightly different features of a graph".

In latter publications in which graphs were applied to analyse the planning of settlements the formulas postulated by Kansky (1962) were used, e.g. $\beta$ measure and cyclomatic number (Drobek 1999). Those measures were used for the analysis of planning of degraded towns in the Silesian area (SW Poland). In order to conduct a morphological analysis of settlements forming conglomerate towns, Szmytkie (2009) modified the measure of the graph development degree (1), basing on formulas presented by Zagożdżon (1977). The formula was then applied by Dymitrow (2012) for the analysis of planning of degraded and restituted towns.

$$
G_{D}=\frac{e\left(v^{2}-v\right)}{v^{2}}
$$

where: $G_{D}$ - graph development degree, $e$ - number of edges, $v$ - number of nodes.
The observations made for this research paper demonstrated that the graph development index in the aforementioned form is too dependent on the graph class expressed by the number of nodes and edges, as a result, it depicts the relative degree of complexity of its structure only in an indirect way. That is why a new, synthetic measure depicting the degree of graph development, independently of the size of a settlement, was needed. In order to construct the index, the following indices were used: $\beta$ index postulated by Kansky (1962), some of the assumptions made by Zagożdżon (1970; 1977), as well as some properties of morphological systems typical of towns and villages (Koter 1994; Szulc 1995; Tkocz 1998).

The following solutions were assumed:

- a graph shape - a settlement structure (buildings arranged in certain forms along streets),

- nodes - single buildings or vertices of sections of streets lined up with buildings,

- edges - sections between the graph nodes (blocks of buildings along streets),

- cycles - closed connections (urban blocks),

- node rank - the number of edges coming out of a node (from 0 in the case of isolated nodes - single developments).

When analysing examples of graphs assigned to a set encompassing small towns and big villages in the south-west region of Poland (Szmytkie 2014), it was noticed that the index showing the degree of graph development should depend on (Fig. 3):

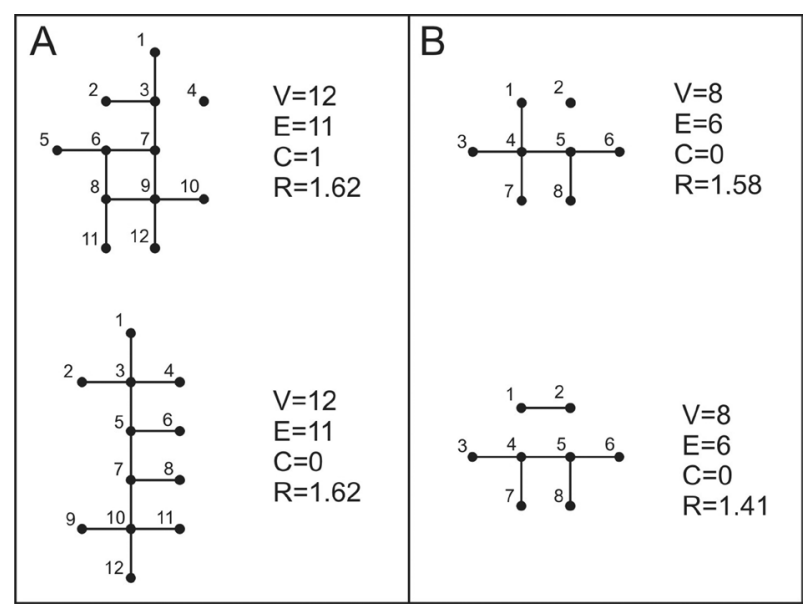

Fig. 3. Graphs differing in the number of cycles (A) or in an average rank of nodes (B).

$\mathrm{V}$ - number of nodes, $\mathrm{E}$ - number of edges, $\mathrm{C}$ - number of cycles, $\mathrm{R}$ - average rank of nodes.

Source: own work. 


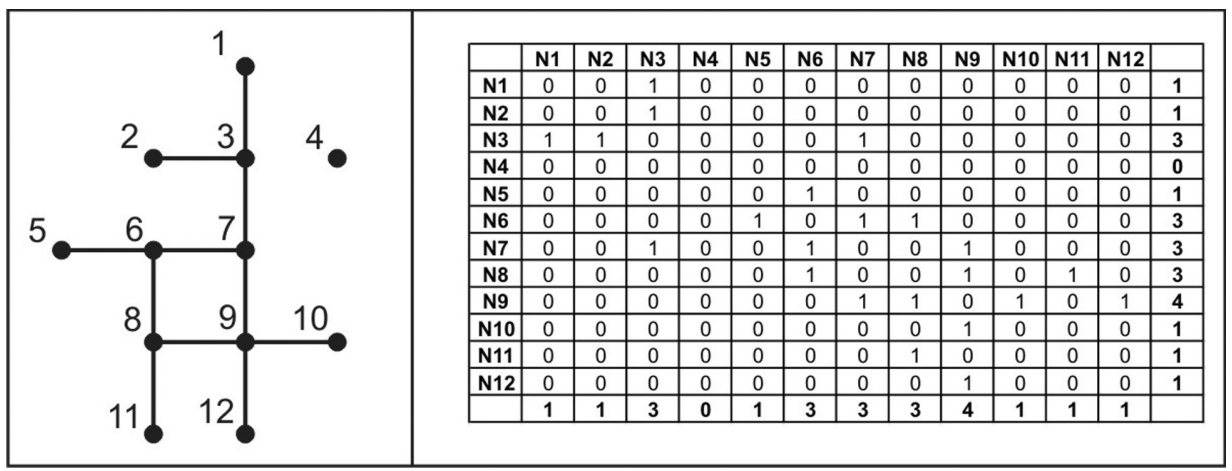

Fig. 4. Incidence matrix (connections between nodes) for a graph example.

Source: own work.

- a relative number of edges in relation to the number of nodes ( $\beta$ index),

- the number of cycles (urban blocks), which evidences the complexity of the spatial pattern of settlement, and, at the same time, is a typical element in shaping the urban landscape,

- an average rank of nodes of a graph, which expresses the degree of complexity of a street network (the rank of nodes should be determined on the basis of an incidence matrix Fig. 4) (Tinkler 1977).

In relation to the above-mentioned assumptions, the formula for the degree of graph development took the following shape (2):

$$
G_{D}=\sqrt{\frac{\sum_{i=1}^{n} r_{i}^{2}}{2 e}} \times \frac{e+2 C}{v}
$$

where: $\sqrt{\frac{\sum_{i=1}^{n} r_{i}^{2}}{2 e}}$-graph development index, $e-$ number of edges, $v$ - number of nodes, $c$ - number of cycles, - index expressing the average rank of nodes in a graph.

The graph development index $\left(G_{D}\right)$ assumes values ranging from 0 to $\infty$, however it is extremely rare for it to exceed the value of 4 , which results from its construction. The index representing an average rank of nodes in a graph takes the minimum value 1 , in the case when the rank of all nodes in a graph is equal to 1 , while the second part of the formula assumes values similar to $\beta$ index (however those values are overcalculated by the presence of cycles). The value of the index expresses the degree of complexity of the spatial pattern of settlement, and, in an indirect way, also its cohesion (as the value of the index is reduced if there are null subgraphs within the graph). High values of the index occur in settlements with complex plans and with a big number of cycles; low values are noted in simple units or in settlements with incoherent spatial patterns (dispersed settlements).

To create graphs for the researched settlements, the author used topographic maps in the scale of 1:25000, which were updated on the basis of digital maps available on geoportal.gov.pl. The graphs were created in Corel Draw X3.

\section{Characteristics of the researched settlements}

To verify the postulated graph development index, the analysis of morphology of the case study of settlements was performed. Due to the intention to interpret the obtained data, it was assumed that settlements included in the analysis should display diverse morphogenesis and have an administrative status; they should also fit in the scope of the urban-rural continuum of a particular region. At the same time it was assumed that the researched area should possess diverse environmental and socio-economic determinants for the settlement network. Referring to the above-mentioned assumptions, the author conducted an analysis in the case of settlements encompassing small towns (up to 6,000 inhabitants) and big villages (above 1,000 inhabitants) located in the south-west region of Poland, which include Lower Silesia and Opole Provinces (voivodeships). In this area there are diverse natural conditions (especially the terrain and land structure) as well as a complex socio-economic situation.

According to the data from 2002, in the southwest region of Poland there were 286 settlements 


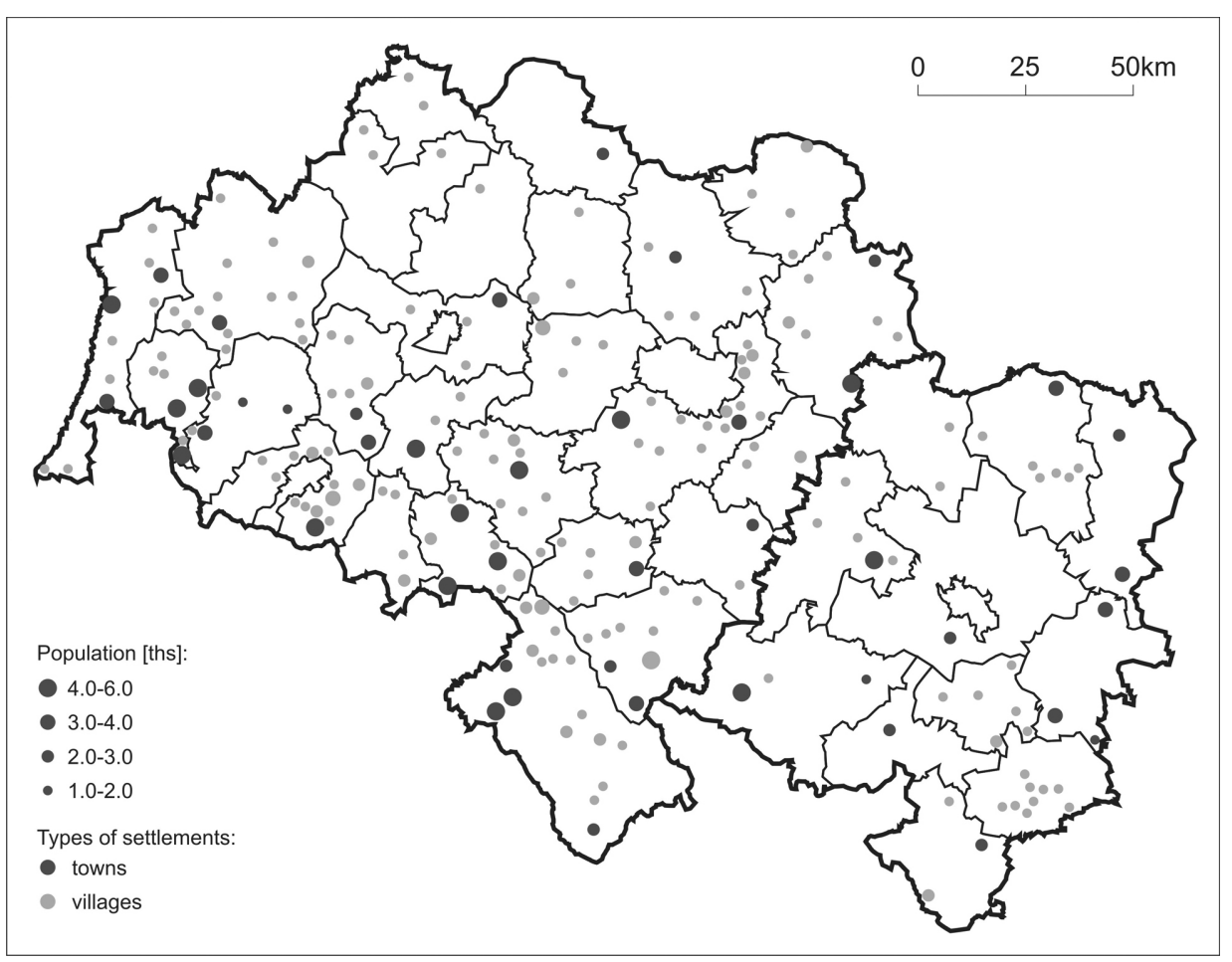

Fig. 5. Distribution and population (2002) of small towns and big villages in the south-west region of Poland. Source: own work.

with the population ranging between 1,000 and 6,000 inhabitants, including 45 towns and 241 villages. The settlements included in the analysis are distributed unevenly (Fig. 5), both in the scale of the whole region and particular units of the administrative division (voivodeships and poviats). In Lower Silesia there are 171 settlements (33 towns and 138 villages), while in Opole Province there are 115 settlements (12 towns and 103 villages).

The analysed set of settlements, despite a similar number of inhabitants and functions in the settlement system, is not homogeneous. That is why, in order to emphasise the main factors influencing the morphological diversity, the analysed dwellings were divided into a dozen types according to specific features. In the typology assumed for this research paper the following criteria were taken into account:

- formal administrative status in 2014 (division of settlements into towns and villages);

- population in 2002 (on the basis of which several size types of settlements were distinguished, different for towns and villages);

- changes in population between the years 1988-2009 (the analysis of this factor led to the distinguishing of settlements with a consider- able increase in population - it was assumed that a significant increase must amount minimally to $20 \%$ in relation to the year 1988);

- location as opposed to the types of physical and geographical regions (division of rural settlements into mountain and lowland villages);

- location of villages in relation to the main cities of the region (distinction of villages located in suburban areas of main urban centres);

- the settlement past, including the period of exercising town status in the case of currently existing towns (as a result of the analysis, we were able to distinguish historical towns with long traditions and new towns, which were granted town privileges after 1945), while in the case of villages, having the status of a town or a settlement in the past (thanks to which it was possible to distinguish degraded towns and former urban settlements), as well as settlements associated with the Soviet Army since 1993 (which made it possible to distinguish former military settlements).

Based on the aforementioned criteria, 22 types of settlements were distinguished (Table 2, Fig. 6).

The main criterion of the division in the case of towns was the year they were formally 
Table 2. Typology of small towns and big villages in the south-west region of Poland.

\begin{tabular}{|c|c|c|c|}
\hline Code & Type of settlements & Population [thous] & Number of settlements \\
\hline HT2 & Historical towns & $3.25-6.0$ & 16 \\
\hline HT1 & Historical towns & $1.6-3.25$ & 17 \\
\hline NT & New towns & $3.0-6.0$ & 14 \\
\hline DT & Degraded towns & $1.0-2.5$ & 12 \\
\hline US & Former urban settlements & $1.5-5.0$ & 6 \\
\hline MS & Former military settlements & $1.0-2.0$ & 3 \\
\hline LV8 & Lowland villages & $3.5-5.0$ & 7 \\
\hline LV7 & Lowland villages & $2.5-3.5$ & 9 \\
\hline LV6 & Lowland villages & $2.0-2.5$ & 14 \\
\hline LV5 & Lowland villages & $1.6-2.0$ & 21 \\
\hline LV4 & Lowland villages & $1.4-1.6$ & 22 \\
\hline LV3 & Lowland villages & $1.25-1.4$ & 20 \\
\hline LV2 & Lowland villages & $1.1-1.25$ & 8 \\
\hline LV1 & Lowland villages & $1.0-1.1$ & 10 \\
\hline MV6 & Mountain villages & $2.0-3.5$ & 11 \\
\hline MV5 & Mountain villages & $1.6-2.0$ & 10 \\
\hline MV4 & Mountain villages & $1.4-1.6$ & $1.25-1.4$ \\
\hline MV3 & Mountain villages & & \\
\hline
\end{tabular}

Source: own work.

granted the town status (and in the case of places where town privileges were reinstated during the postwar period, the year a town was first established). The age criterion is also reflected in the morphology of towns, that is why a conclusion may be drawn that both distinguished types (historical and new towns) considerably differ as to determining morphogenetic features for each type. Historical towns in the south-west region of Poland were established mainly during the medieval period (Krzysztofik 2007), that is why their layouts display features characteristic of that

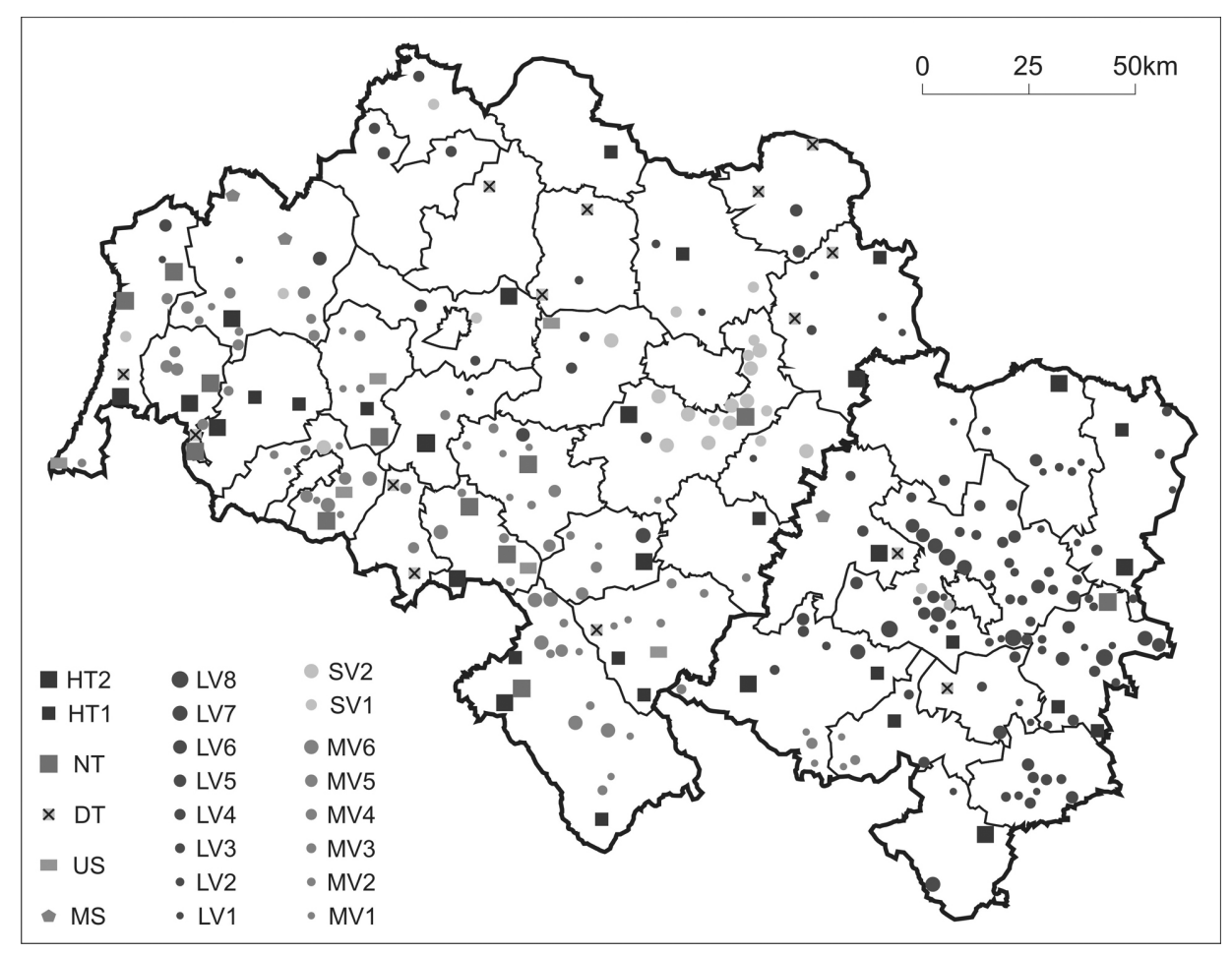

Fig. 6. Types of small towns and big villages in the south-west region of Poland. Source: own work. Explanations of types in Table 2. 
period: regular planning with a market square and a chessboard layout of streets, the major part encompassed by multi-storey tenement houses (Eysymontt 2009; Słodczyk 2012). New towns were established as a result of granting town privileges to former villages, that is why those settlements maintained the rural development and layout. However, the postwar period was the time of many changes in those settlements, also morphological ones. As a result, their layout obtained urban features (with a complicated spatial pattern and multi-family housing estates). Because of the substantially larger population size, historical towns were additionally divided into two size categories, thanks to which it was possible to measure the degree to which the town size influences its morphology.

Among all rural settlements, the author distinguished units which stood out among typical villages because of their settlement history, which, in turn, influenced their morphology. Despite the size of current population, the following settlements were assigned to separate categories: degraded towns (settlements which used to have the town status, but lost it in the 18th and 20th century), former urban settlements (which were never granted the formal town status) and former military settlements, which, in the postwar period (until 1993), were settled by Soviet Army troops.

Degraded towns, as a result of their settlement past (possession of the town status for a long period of time) and keeping their spatial structures after the loss of town privileges, possess layouts typical of towns, hence, in a morphological sense, they resemble towns more than villages (Drobek 1999; Dymitrow 2013). Former urban settlements, in spite of the fact that they were never granted the town status, were assigned to a different category, as their compact design, which was urban in character, was one of the main criteria applied for their distinction. A separate category was created for former military settlements where Soviet Army troops were based until 1993. The distinction of the aforementioned category resulted mainly from the character of those settlements, which, in the period of Soviet Army quartering, served as towns with complex spatial planning and multi-family housing estates, mainly with multi-dwelling units typical of towns.

The remaining rural settlements in the southwest region of Poland were divided on the basis of three basic factors: location, the population size and the dynamics of population changes. Firstly, villages were divided according to their location in reference to the two types of landform into: mountain villages (located in the Sudety Mountains and the Sudety Foothills) and lowland villages (located in the Silesian Lowlands). The aforementioned criterion was applied because the settlements displayed various shapes (spatial patterns) in particular types of geographical regions (Szulc 1995). In the Sudety Mountains and the Sudety Foothills the dominant type of villages is double-row (Waldhufen) and, rarely, cluster villages and street villages, while in the lowland part of Silesia there are mainly street villages, cluster villages, oval green villages and street-green villages. Suburban villages were categorised as separate, as they undergo intensive suburbanisation processes, because of their proximity to main urban centres, also in the scope of morphology; as a result they became more similar to nearby housing estates (inner suburbs).

In the second stage, because of substantial differences in sizes within each type, villages from the three established types (lowland, mountain and suburban), were divided into classes according to the population size ( 8 size classes in the case of lowland villages, 6 classes in the case of mountain villages and 2 classes in the case of suburban villages). The division of rural settlements based on their population size assumes a graduate change in the morphology of a settlement together with an increase in the number of inhabitants, which results from the premises of the concept of the rural-urban continuum (Cloke 1977; Kirk 1980), and the statistical criterion commonly applied in the process of a town assignment. The notion of town requires a certain population minimum, which results from the urban character of a settlement after exceeding the certain population size (Maik 1992).

\section{Graph development index in small towns and big villages}

Small towns and big villages in the southwest region of Poland exhibit diverse planning, which results from the diversity of their spatial patterns. It is visible in the value of the graph development index $\left(G_{D}\right)$. The average value of the 
Table 3. Small towns and big villages in the south-west region of Poland with the highest and the lowest values of graph development index $\left(\mathrm{G}_{\mathrm{D}}\right)$.

\begin{tabular}{|c|c|c|c|}
\hline Rank & Name of settlement & Type of settlement & Graph development index value \\
\hline 1 & Lewin Brzeski & HT2 & 3.795 \\
\hline 2 & Pieńsk & NT & 3.737 \\
\hline 3 & Otmuchów & HT2 & 3.678 \\
\hline 4 & Węgliniec & NT & 3.636 \\
\hline 5 & Byczyna & HT2 & 3.585 \\
\hline 282 & Ciechanowice & DT & 0.703 \\
\hline 283 & Milików & MV2 & 0.700 \\
\hline 284 & Brynica & MV2 & 0.694 \\
\hline 285 & Ścinawka Dolna & MV2 & 0.645 \\
\hline 286 & Głuszyca Górna & & 0.547 \\
\hline
\end{tabular}

Source: own work.

index in the analysed set of settlements amounts to 1.874 , with the standard deviation amounting to 0.667 and the coefficient of variation on the level of 0.36 . Moreover, the conducted analysis indicated that the towns (2.545) and settlements with the urban or quasi-urban past (2.207) display considerably higher values of the graph development index than the remaining rural settlements (1.700) (Table 3).

Among the distinguished types of settlements, the ones with the highest values of the graph development index are HT2 historical towns (2.762) (Table 4). HT1 historical towns are different types of settlements with a similar level of complexity of a spatial pattern (2.508). Low values of the coefficient of variation in both types are the evidence of a morphological similarity of settlements, despite their various sizes (Fig. 7). This results mainly from the urban patterns introduced there in the Middle Ages. Towns established at that time displayed a chessboard layout of streets, with separated urban blocks filled in with compact built-up areas, hence a high number of cycles and a high ratio value of the number of edges and nodes. Towns with a compact construction demonstrate high values in both groups, while towns with inconsistent spatial structures exhibit lower values, especially those whose development was a result of incorporation of neighbouring rural settlements. Another factor which influenced the morphology of small towns was also topography, which can lead to a

Table 4. Graph development index $\left(\mathrm{G}_{\mathrm{D}}\right)$ in small towns and big villages in the south-west region of Poland.

\begin{tabular}{|c|c|c|c|c|c|}
\hline \multirow{2}{*}{ Code } & \multirow{2}{*}{ Type of settlements } & \multirow{2}{*}{ Population [ths] } & \multirow{2}{*}{ Number of settlements } & \multicolumn{2}{|c|}{ Graph development index } \\
\hline & & & & Average value & Coefficient of variation \\
\hline HT2 & Historical towns & $3.25-6.0$ & 16 & 2.762 & 0.23 \\
\hline HT1 & Historical towns & $1.6-3.25$ & 17 & 2.508 & 0.18 \\
\hline NT & New towns & $3.0-6.0$ & 14 & 2.307 & 0.37 \\
\hline DT & Degraded towns & $1.0-2.5$ & 12 & 2.218 & 0.32 \\
\hline US & Former urban settlements & $1.5-5.0$ & 6 & 2.160 & 0.15 \\
\hline MS & Former military settlements & $1.0-2.0$ & 3 & 2.250 & 0.39 \\
\hline LV8 & Lowland villages & $3.5-5.0$ & 4 & 2.690 & 0.23 \\
\hline LV7 & Lowland villages & $2.5-3.5$ & 7 & 2.123 & 0.20 \\
\hline LV6 & Lowland villages & $2.0-2.5$ & 9 & 1.667 & 0.30 \\
\hline LV5 & Lowland villages & $1.6-2.0$ & 14 & 1.895 & 0.31 \\
\hline LV4 & Lowland villages & $1.4-1.6$ & 21 & 1.831 & 0.26 \\
\hline LV3 & Lowland villages & $1.25-1.4$ & 22 & 1.695 & 0.28 \\
\hline LV2 & Lowland villages & $1.1-1.25$ & 20 & 1.529 & 0.24 \\
\hline LV1 & Lowland villages & $1.0-1.1$ & 20 & 1.619 & 0.29 \\
\hline MV6 & Mountain villages & $2.0-3.5$ & 8 & 1.407 & 0.33 \\
\hline MV5 & Mountain villages & $1.6-2.0$ & 10 & 1.555 & 0.36 \\
\hline MV4 & Mountain villages & $1.4-1.6$ & 11 & 1.404 & 0.30 \\
\hline MV3 & Mountain villages & $1.25-1.4$ & 10 & 1.489 & 0.22 \\
\hline
\end{tabular}

Source: own work. 

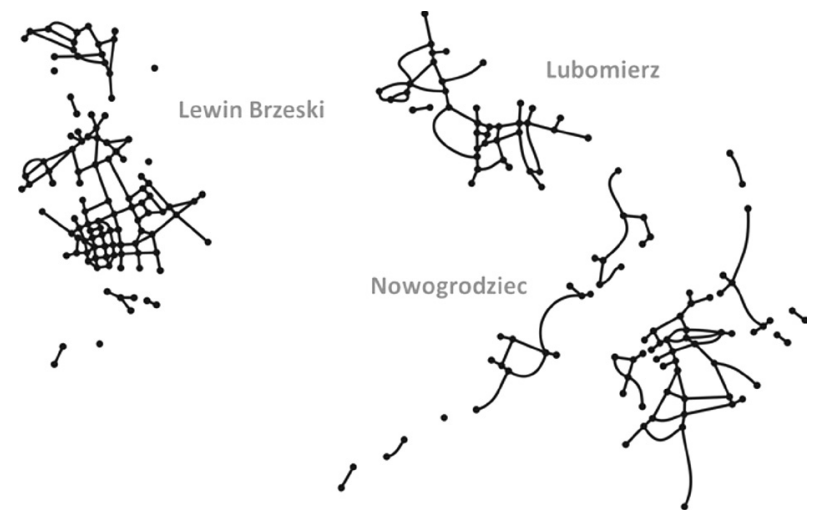

Fig. 7. Graphs depicting the morphology of historical towns (HT1-HT2).

Source: own work.

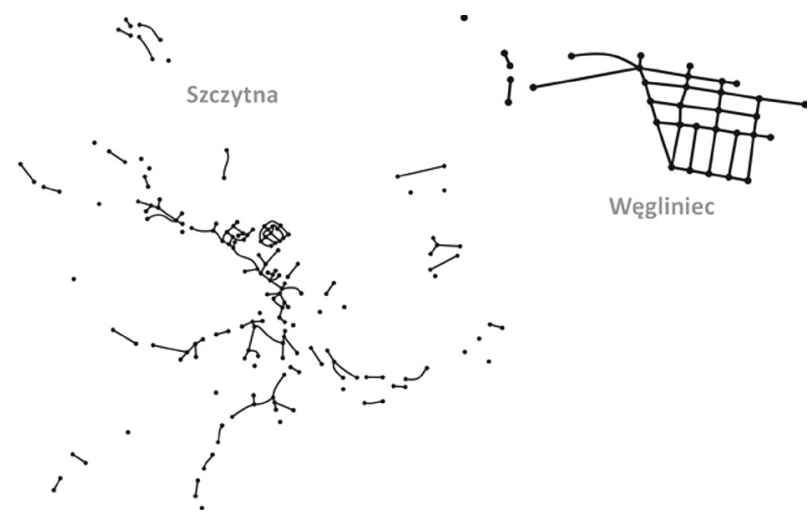

Fig. 8. Graphs depicting the morphology of new towns (NT).

Source: own work.

reduction in the spatial coherence of a settlement as a result of the necessity of fitting its spatial pattern to the local topography.

Postwar towns (NT) exhibit a considerably lower value of the graph development index than historical towns of a similar size (2.307). This is due to the fact that the group also included the

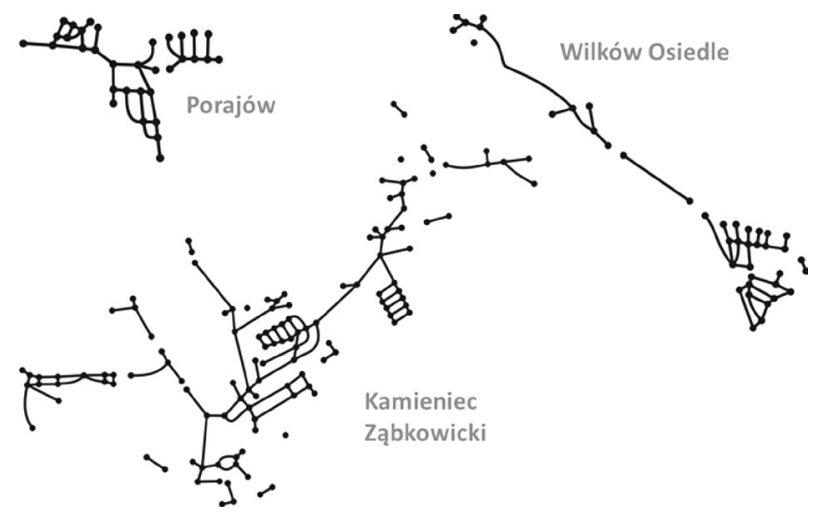

Fig. 9. Graphs depicting the morphology of former urban settlements (US).

Source: own work.
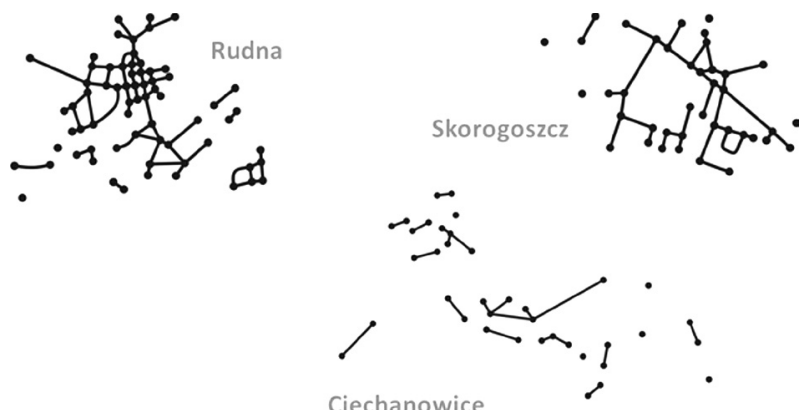

Ciechanowice

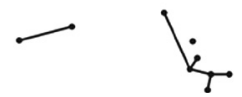

Fig. 10. Graphs depicting the morphology of degraded towns (DT).

Source: own work.

towns with not very coherent spatial patterns (Fig. 8), the development of which during the postwar period proceeded as a result of incorporation of neighbouring rural settlements. However, some small towns in the region, which were granted the town status after 1945, exhibit coherent spatial structures, which results in a substantially high value of the coefficient of variation within this group (0.37). It affects particularly industrial centres and transport hubs located in the lowland part of Silesia. A lower value of the index may also result from the origin of a particular settlement in the group that developed quickly from the units displaying a typical rural layout. This assumption is also confirmed by a relatively low average value of the graph development index in the case of former urban settlements (US) (2.160), which display similar morphogenesis. The majority of settlements in this group kept a layout typical of rural settlements (Fig. 9).

Degraded towns (DT) display a considerably high average value of the graph development index (2.218). Nevertheless, they are diverse in

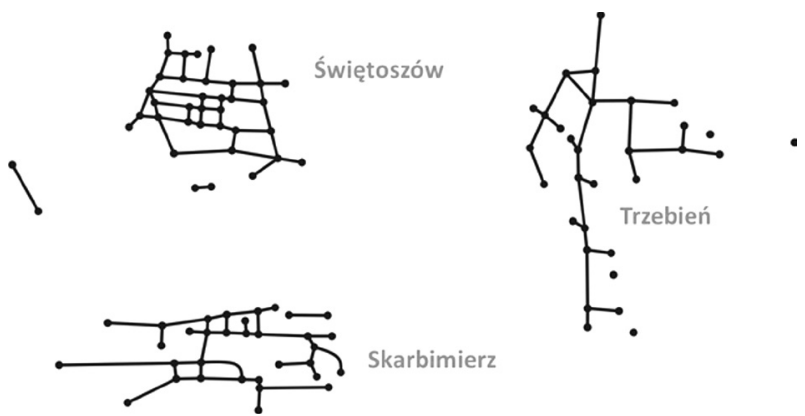

Fig. 11. Graphs depicting the morphology of former military settlements (DT). Source: own work. 
their morphology (Fig. 10), which is reflected in a considerably high value of the coefficient of variation (0.32). This, in turn, results from different degrees of maintaining their urban character. In this group there are settlements with typical town planning, as well as settlements with strongly degraded urban arrangements, and even incoherent and unreadable spatial structures. A wide diversity concerning the value of the graph development index is also visible in former military settlements (Fig. 11).

Among the remaining types of rural settlements, big lowland villages (LV7-LV8) and suburban villages (SV1-SV2) displayed high average values of the graph development index. In the case of suburban villages (Fig. 12) the aforementioned result stems from morphological changes in villages influenced by heavy construction traffic in the areas surrounding big cities. As a result, in suburban areas, morphological units typical of towns appeared (detached houses, terraced houses and multi-family housing estates), which led to an increase in the complexity of spatial structures of those settlements. Therefore, it can be stated that the the suburbanisation process is manifested by the progression of morphological similarity of suburban settlements to towns, understood as neighbouring, outlying housing developments with housing functions.

High average values of the graph development index in the case of lowland villages apply only to the biggest settlements (above 2,500 inhabitants), which is a sign of assuming an urban character by a settlement once it exceeds a certain population number. Big villages located in the lowland part of the south-west region of Poland
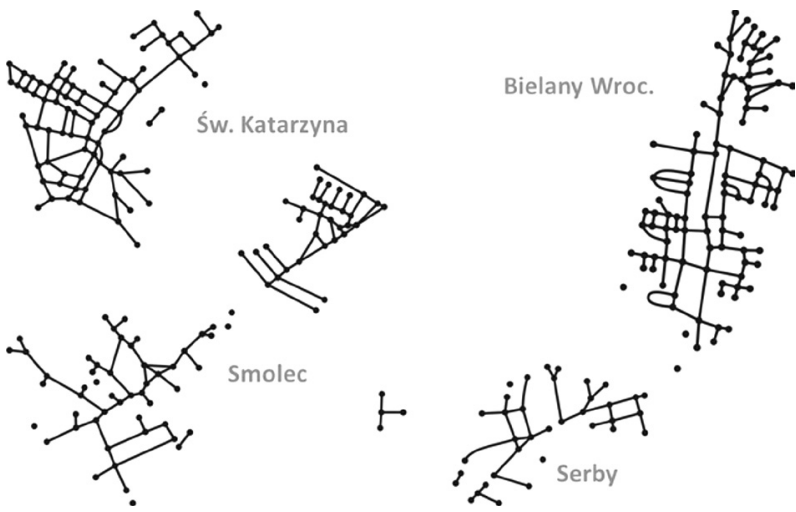

Fig. 12. Graphs depicting the morphology of suburban villages (SV).

Source: own work.

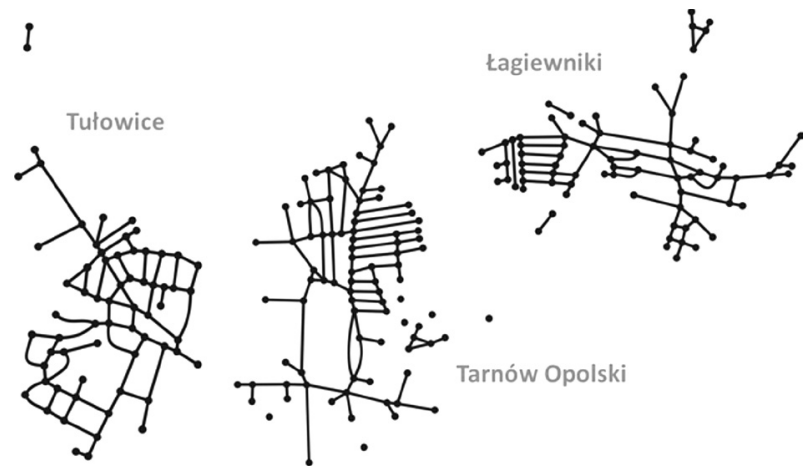

Fig. 13. Graphs depicting the morphology of lowland villages with the population below 2,500 inhabitants (LV7-LV8).

Source: own work.

display complex, multiway planning (Fig. 13); as a result, they become similar to towns in the morphological aspect. The remaining size categories of lowland villages (LV1-LV6) present considerably lower average values of the graph development index; however, the set is significantly diverse. When analysing the distribution of the index values it is visible that the degree of spatial pattern development depends on the morphological type of a settlement (Fig. 14). High values of the graph development index in the case of lowland villages are assumed, in particular, by cluster villages, oval green villages and street-green villages, whose graphs include a high number of cycles; lower values are acquired by street villages with simple spatial patterns; the lowest values are assumed by villages with incoherent spatial patterns, which often include hamlets (this refers in particular to settlements located near dense

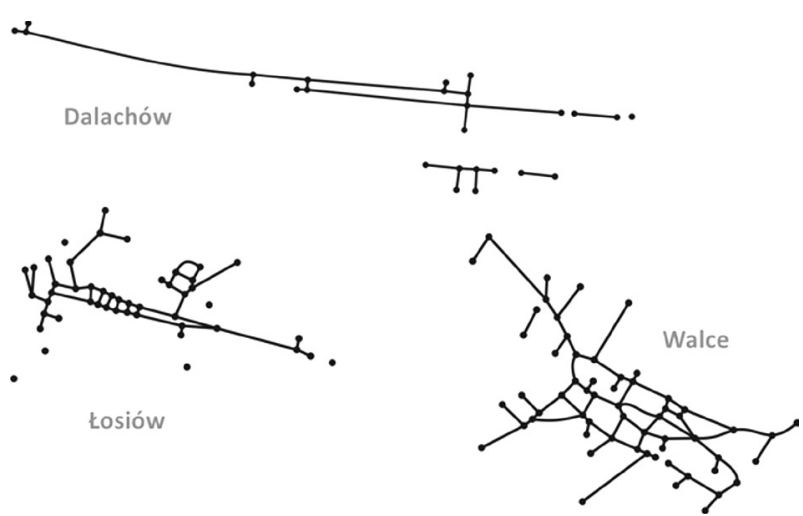

Fig. 14. Graphs depicting the morphology of lowland villages with the population ranging from 1,000 to 2,500 inhabitants (LV1-LV6). Source: own work. 


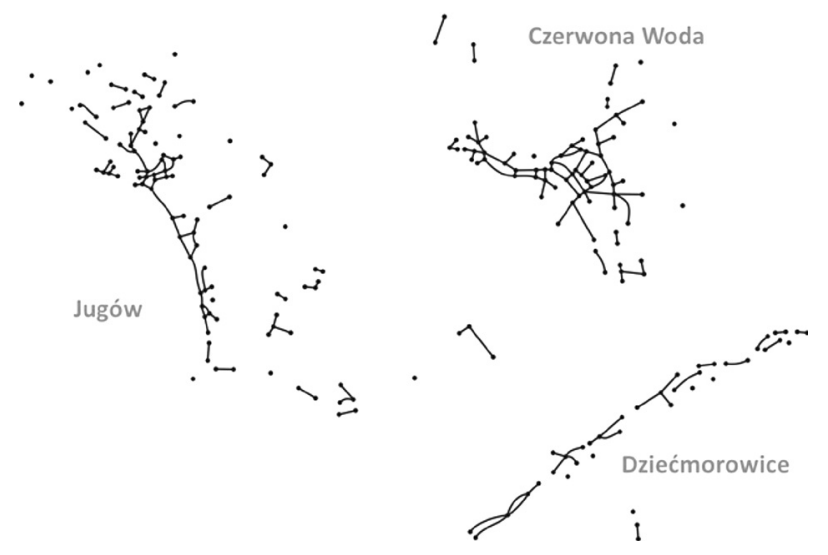

Fig. 15. Graphs depicting the morphology of mountain villages (MV1-MV6).

Source: own work.

forest complexes, on weak, sandy soil, which hinders the development of farming).

Other rural settlements which obtained low values of the graph development index are mountain villages (MV1-MV6), in spite of their size category (average value of the index in this case amounted to 1.410; moreover, only in few villages $G_{D}$ exceeded the value of 2.0). It results from the morphological types predominant in this part of the region and the necessity of adjusting spatial patterns to the local topography (Fig. 15). Among mountain villages, relatively high values of the graph development index were obtained by villages with a multiway spatial layout and double-row villages with a dense development. Low values of the analysed parameter were noticed in particular in double-row villages with a spread spatial pattern, located especially in the upper parts of valleys, with numerous hamlets and scattered development (in this case the size

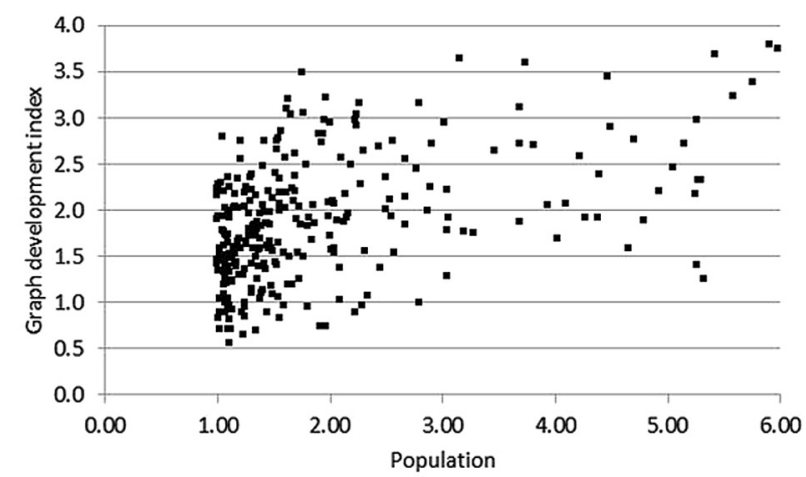

Fig. 16. Population and graph development index value for small towns and big villages in the southwest region of Poland.

Source: own work. of a settlement does not significantly influence its morphology).

The analysis of the values of the graph development index in relation to the particular types of small towns and big villages in the south-west region of Poland demonstrated a dependency of the researched parameter, not only on the morphogenesis of a settlement or its geographical (and even topographical) location, but also on the size of a settlement expressed by its population size (Fig. 16). The correlation coefficient between the value of the graph development index and the population size equals 0.47 , which proves a rather strong dependence, however its value is substantially lowered by mountain villages, in which case the degree of the graph development index does not depend on the size of a settlement (a product-moment correlation coefficient for mountain villages amounts to 0.04 ).

\section{Summary and discussion}

According to the author, the graph development index presented in this paper serves to determine the degree of spatial pattern development. Referring to Zagożdżon (1977), it can be also assumed that it is the first synthetic index, which depicts several features defining the graph structure (i.e. the number of edges in relation to the number of nodes, the number of cycles, ranks of nodes in a graph and the number of isolated subgraphs), despite the graph size. As a result, it can be useful in an analysis of settlement planning in different types of analyses (static, dynamic and comparative). The graph development index can be applied not only in geographical and settlement research, but also as one of the auxiliary criteria in a formal administrative procedure of granting town status in Poland or in other countries.

The importance of the proposed graph development index is underlined by the analytical conclusions of the study. The analysis of the morphology of small towns and large villages in the south-west region of Poland made the verification of the examined research hypotheses possible:

1. Studies have confirmed that the morphology of settlements depends on the category of a settlement, settlement history, its size (pop- 
ulation) and location. The following remarks have been made:

- small towns and settlements with the urban past (degraded towns, former urban settlements) have more complex layouts, which is expressed by higher values of the graph development index;

- historical towns with long urban traditions have developed a specific type of a landscape, which manifests itself in their complex spatial pattern, compact development and a considerable share of multi-family housing;

- former urban settlements, in the morphological aspect, are similar to new towns (in the post-war period they were subject to similar processes), whereas degraded towns are similar to historical towns (the morphological differences among degraded towns derive from different levels of the preservation of urban features);

- a geographic location affects more the morphology of rural settlements, whereas the urban morphology, especially the morphology of historical towns, is less dependent on natural conditions.

2. Urbanisation processes taking place in rural areas lead to a gradual transformation from rural to urban, which is also reflected in the morphology of settlements. This applies in particular to large villages located far from main urban centres and suburban settlements, which became similar to the neighbouring and outlying housing developments.

3. Within given types of settlements the greater morphological diversity is demonstrated by:

- units formed in a spontaneous way rather than by units formed in a planned manner (e.g. new towns, which developed in the postwar period as a result of the transformation of rural settlements under the influence of industry or specialised service activities), which are more diversified than historical towns of similar size;

- settlements undergoing dynamic changes in recent years rather than by settlements developing in a long-term and evolutionary way (admittedly, the dynamic development of the construction activity in suburban areas contributed to a certain morphological unification of settlements, which is caused by the spread of uniform urban patterns);
- larger settlements rather than by smaller ones, which is indicated by the correlation coefficient between the population and the coefficient of variation, as well as an increase in the morphological differences between some types of settlements connected with the population growth.

\section{References}

Arlinghaus S.L., Arlinghaus W.C., Harary F., Arlinghaus S.L., 2002. Graph theory and geography: An interactive view (eBook). John Wiley and Sons, Wiley-Interscience Series in Discrete Mathematics and Optimization, http:// www. wiley. com/.

Beineke L.W., Wilson R.J. (eds), 2004. Topics in algebraic graph theory. Cambridge University Press, Cambridge.

Cloke P.J., 1977. An index of rurality for England and Wales. Regional Studies 11: 31-46.

Conzen M.R.G., 1960. Alnwick, Northumberland: A study in town plan analysis. Institute of British Geographers, London.

Conzen M.R.G., 1962. The plan analysis of an English city centre (Newcastle upon Tyne). In: Proccedings of the International Geographical Union Symposium in Urban Geography, Lund 1960. Lund Studies in Geography: 383-414.

Conzen M.R.G., 1968. The use of town plans in the study of urban history. In: Dyos H.J. (ed.), The study of urban history. Edward Arnold, London: 113-130.

Doi S., 1969. Graph theoretical measure of status subspace on geographical space. Graphs Reports of Tokyo Metropolitan University 4. Tokyo.

Drobek W., 1999. Rola miast zdegradowanych w sieci osadniczej Ślaska (The role of degraded towns in the settlement system of Silesia). Wydawnictwo Instytutu Śląskiego w Opolu, Opole.

Ducruet C., Lugo I., 2013. Structure and dynamics of transportation networks: Models, methods, and applications. In: Rodrigue J.P., Notteboom T.E., Shaw J. (eds), The SAGE Handbook of Transport Studies. SAGE: 347-364.

Dymitrow M., 2012. The hidden face of urbanity. Morphological differentiation of degraded and restituted towns in Poland in the context of the efficacy of the national administrative system. Degree Project for Master of Science. University of Gothenburg, Gothenburg.

Eysymontt R., 2009. Kod genetyczny miasta. Średniowieczne miasta lokacyjne Dolnego Śląska na tle urbanistyki europejskiej (The genetic code of a town. Medieval location towns of Lower Silesia relating to the European urban planning). Wydawnictwo Via Nova, Wrocław.

Garrison W.L., 1968. Connectivity of the Interstate Highway System. Papers of the Regional Science Association 6: 121-137.

Gross J., Yellen J., 1999. Graph theory and its application. CRC Press, London.

Hage P., 1979. Graph theory as a structural model in cultural anthropology. Annual Review of Anthropology 8(1): 115-136.

Haggett P., 1965. Locational analysis in human geography. St. Martin's Press, London. 
Haggett P., Chorley R.J., 1969. Network analysis in geography. Edward Arnold, London.

Harary F., 1969. Proof techniques in graph theory. Academic Press.

Harary F., 1970. Graph theory as a structural model in the social sciences. In: Harris B. (ed.), Graph theory and its applications. Academic Press, New York: 1-16.

Harris B., 1985. Urban simulation-models in regional science. Journal of Regional Science 25: 545-567.

Hillier B., 1996. Space is the machine: A configurational theory of architecture. Cambridge University Press, Cambridge.

Hillier B., Hanson J., 1984. The social logic of space. Cambridge University Press, Cambridge.

James G.A., Cliff A.D., Haggett P., Ord J.K., 1970. Some discrete distributions for graphs with applications to regional transport networks. Geografiska Annaler 52B(1):14-21.

Jażdżewska I., 2008. Przemiany miejskiej sieci osadniczej w Polsce $w$ świetle metod matematycznych (Transformations of the urban system in Poland in the light of mathematical methods). Wydawnictwo Uniwersytetu Łódzkiego, Łódź.

Kansky K.J., 1963. Structure of transport networks: Relationships between network geometry and regional characteristics. Department of Geography, Research Papers 84. University of Chicago, Chicago.

Kirk W., 1980. The rural-urban continuum: Perception and reality. In: Enyedi G., Meszaros J. (eds), Development of settlement systems. Budapest: 11-19.

Koter M., 1994. Od fizjonomii do morfogenezy i morfologii porównawczej. Podstawowe zagadnienia teoretyczne morfologii miast (From the physiognomy to the morphogenesis and the comparative morphology. Essential theoretical issues of the urban morphology). In: Koter M., Tkocz J. (eds), Zagadnienia geografii historycznej osadnictwa $w$ Polsce (Issues of the historical geography of the settlements in Poland), Torun - Łódź: 26-31.

Koter M., Kulesza M., 2010. The study of urban form in Poland. Urban Morphology 14(2): 111-120.

Krüger M.J.T., 1979. An approach to built-form connectivity at an urban scale: System description and its representation. Environment and Planning B: Planning and Design 6(1): 67-88.

Krzysztofik R., 2007. Lokacje miejskie na obszarze Polski. Dokumentacja geograficzno-historyczna (Locations of towns in Poland. Geographical and historical documentation). Wydawnictwo Uniwersytetu Śląskiego, Katowice.

Levine J., Landis J., 1989. Geographic information systems for local planning. Journal of the American Planning Association 55: 209-220.

Lienau C., 1973. A matter of terminology: Rural settlements. Geoforum 4(4): 92-94.

Łoboda J., 1973. Rozwój systemu sieci nadającej program telewizyjny w Polsce w ujęciu grafowym (Development of a TV network in Poland according to the graph theory). Czasopismo Geograficzne 44(1): 13-31.

Maik W., 1977. A graph theory approach to the hierarchical ordering of elements of the settlements systems. Questiones Geographicae 4: 95-108.

Maik W., 1992. Podstawy geografii miast (The essentials of urban geography). Uniwersytet Mikołaja Kopernika, Toruń.

Marshall S., 2004. Streets and patterns. Routledge, London.

Miszewska B., 1976. Morfologia sieci osadniczej jako układu linii (Morphology of the settlement network as the system of lines). Studia Geograficzne 22. Wydawnictwo Uniwersytetu Wrocławskiego, Wrocław.

Moriconi-Ebrard F., 1993. L'urbanisation du monde, depuis 1950 (Urbanisation of the world, since 1950). Anthropos, Paris.

Newman M.E.J., 2010. Networks: An introduction. Oxford University Press, Oxford.

Nystuen J.D., Dacey M.F., 1968. A graph theory interpretation of nodal regions. Geographia Polonica 15: 135-151.

Öre O., 1962. Theory of graphs. American Mathematical Society, Providence.

Öre O., 1990. Graphs and their uses. Cambridge University Press, Cambridge.

Páez A., Scott D.M., 2004. Spatial statistics for urban analysis: A review of techniques with examples. GeoJournal 61: 53-67.

Porta S., Crucitti P., Latora V., 2006. The network analysis of urban streets: A primal approach. Environment and Planning B: Planning and Design 33(5): 705-725.

Ratajczak W., 1980. Analiza i modele wpływu czynników społeczno-gospodarczych na kształtowanie się sieci transportowej (The analysis and models of the influence of social and economic factors on the forming of transportation network). PWN, Warszawa.

Ratti C., 2004. Space syntax: Some inconsistencies. Environment and Planning B: Planning and Design 31(4): 501-511.

Runge J., 2006. Metody badań w geografii społeczno-ekonomicznej. Elementy metodologii, wybrane narzedzia badawcze (Research methods in social and economic geography. Elements of methodology, chosen research tools). Wydawnictwo Uniwersytetu Śląskiego, Katowice.

Schlüter O., 1899. Bemerkungen zur Siedlungsgeographie (Some remarks for settlement geography), Geographische Zeitschrift 5: 65-84.

Słodczyk J., 2012. Historia planowania $i$ budowy miast (The history of the planning and construction of cities). Wydawnictwo Uniwersytetu Opolskiego, Opole.

Szmytkie R., 2009. Miasta-zlepieńce na Ślasku Dolnym i Opolskim (Urban conglomerates in Lower and Middle Silesia). Rozprawy Naukowe Instytutu Geografii i Rozwoju Regionalnego 6. Uniwersytet Wrocławski, Wrocław.

Szmytkie R., 2014. Metody analizy morfologii i fizjonomii jednostek osadniczych. Rozprawy Naukowe Instytutu Geografii i Rozwoju Regionalnego 35. Uniwersytet Wrocławski, Wrocław.

Szulc H., 1995. Morfogeneza osiedli wiejskich w Polsce (The morphogenesis of rural settlements in Poland). Instytut Geografii i Przestrzennego Zagospodarowania PAN, Warszawa.

Taylor Z., 1974. Metody grafowe w badaniach przestrzenno-ekonomicznych (Graph methods in spatial and economic studies). Czasopismo Geograficzne 45(3): 337-348.

Taylor Z., 1975. Charakterystyka zmian w strukturze sieci transportowych $w$ ujęciu grafowym (Changes in the structure of transport networks according to the graph theory). Przeglad Geograficzny 47: 501-517.

Thomson R.C., Richardson D.E., 1995. A graph theory approach to road network generalisation. In: Proceeding of the 17th International Cartographic Conference: 1871-1880.

Tinkler K.J., 1977. An introduction to graph theoretical methods in geography. Concepts and techniques in modern geography 14.

Tkocz J., 1998. Organizacja przestrzenna wsi w Polsce (Spatial organisation of villages in Poland). Wydawnictwo Uniwersytetu Śląskiego, Katowice. 
Whitehand J.W.R., 1987. Urban morphology. In: Pacione M. (ed.), Historical geography: Progress and prospect. Routledge, London: 250-276.

Whitehand J.W.R., 1992. The urban landscape: Issues and perspectives. In: Whitehand J.W.R., Larkham P.J. (eds), Urban landscapes. International perspectives. Psychology Press, London - New York: 1-19.

Whitehand J.W.R., 2001. British urban morphology: The Conzenian tradition. Urban Morphology 5(2):103-109.

Xie F., Levinson D.M., 2007. Measuring the structure of road networks. Geographical Analysis 39(3): 336-356.

Xie F., Levinson D.M., 2009. Modeling the growth of transportation networks: A comprehensive review. Networks and Spatial Economics 9(3): 291-307.
Xie F., Levinson D.M., 2011. Evolving transportation networks. Springer, New York.

Zagożdżon A., 1970. Metody grafowe w badaniach osadniczych ze szczególnym uwzględnieniem morfologii siedlisk (Graph methods in settlement studies with particular reference to the morphology of settlements). In: Przeglad Geograficzny 42(2): 335-348.

Zagożdżon A., 1977. Wykorzystanie metod i technik grafowych $\mathrm{w}$ analizie struktur przestrzennych (Using graph methods and techniques in analysis of spatial structures). In: Chojnicki Z. (ed.), Metody ilościowe i modele w geografii (Quantitative methods and models in geography). PWN, Warszawa: 158-169. 